\title{
Complejos moleculares de la señalización adrenérgica
}

\author{
Rocío Alcántara-Hernández y Aurelio Hernández-Méndez² \\ 'Universidad Nacional Autónoma de México, Instituto de Fisiología Celular, Departamento de Biología Celular y Desarrollo, Ciudad de México; \\ 2Universidad Autónoma de San Luis Potosí, Facultad de Medicina, Departamento de Fisiología y Biofísica, San Luis Potosí. México
}

\begin{abstract}
Resumen
La adrenalina y la noradrenalina se unen a receptores membranales de la superfamilia de receptores acoplados a proteínas G (GPCR) en las células blanco, donde modulan respuestas fisiológicas tales como el metabolismo, vasoconstricción, vasodilatación y proliferación. La alteración en su función está asociada con hipertensión, hiperplasia prostática benigna e hipertrofia cardiaca. En respuesta a la adrenalina, los receptores forman complejos de señalización, lo que permite que la acción adrenérgica sea específica, rápida y eficiente. Estos complejos de señalización o signalosomas están integrados por cinasas, fosfatasas, proteínas adaptadoras y de andamio, que en conjunto modulan la función del receptor. La manipulación de cada interacción proteína-proteína del complejo de señalización adrenérgico emerge como una estrategia terapéutica prometedora para el diseño de fármacos que modulen la acción adrenérgica y ayuden a definir su significado fisiopatológico. Un modelo biológico importante para realizar estos estudios es el corazón, ya que expresa todos los receptores adrenérgicos; en la actualidad se han descrito varios signalosomas cardiacos. La espectrometría de masas (proteómica), manipulación genética y ensayos bioquímicos como el doble híbrido o la coinmunoprecipitación son herramientas que se emplean en estos estudios.
\end{abstract}

PALABRAS CLAVE: Adrenalina. Noradrenalina. Receptores adrenérgicos. Receptores acoplados a proteínas G. Complejos de señalización. Signalosomas.

\begin{abstract}
Adrenaline and noradrenaline bind to membrane receptors of the superfamily of G protein-coupled receptors (GPCR) in target cells, where they modulate physiological responses such as metabolism, vasoconstriction, vasodilation and proliferation. Alteration in their function is associated with conditions such as hypertension, benign prostatic hyperplasia and cardiac hypertrophy. In response to adrenaline, receptors form signaling complexes, which enables adrenergic action to be specific, rapid and efficient. These signaling complexes or signalosomes are composed of kinases, phosphatases, and adapter and scaffold proteins, which together modulate the receptor function. Manipulation of each protein-protein interaction of the adrenergic signaling complex emerges as a promising therapeutic strategy for the design of drugs that modulate adrenergic action and help to define its pathophysiological significance. An important biological model to perform these investigations is the heart, since it expresses all adrenergic receptors; to date, several heart signalosomes have been described. Mass spectrometry (proteomics), genetic manipulation and biochemical assays, such as two-hybrid and co-immunoprecipitation assays, are tools that are used in these studies.
\end{abstract}

KEY WORDS: Adrenaline. Noradrenaline. Adrenergic receptors. G protein-coupled receptors. Signaling complexes. Signalosomes.

Correspondencia:

Rocío Alcántara-Hernández

E-mail: ralcanta@ifc.unam.mx
Fecha de recepción: 05-07-2016

Fecha de aceptación: 06-07-2016

DOI://dx.doi.org/10.24875/GMM.18002390
Gac Med Mex. 2018;154:223-235

Disponible en PubMed

www.gacetamedicademexico.com 


\section{Introducción}

La adrenalina (ADRE) y la noradrenalina (NA), hormona y neurotransmisor respectivamente, son producidos a partir de la L-tirosina en dos fuentes en el organismo: las terminaciones nerviosas simpáticas, que liberan NA sobre los órganos efectores después de la estimulación, y las células cromafines de la médula suprarrenal, que en realidad son neuronas simpáticas posganglionares y fuente principal de síntesis, almacén y liberación de ADRE y NA bajo la estimulación de receptores nicotínicos de acetilcolina. ${ }^{1}$

Ambas catecolaminas (ADRE y NA), llamadas con este nombre por contener en su estructura química un anillo de catecol (1,2-dihidroxibenceno) median una gran variedad de funciones esenciales para el organismo, entre las que se encuentran la vasodilatación, vasoconstricción, proliferación, presión sanguínea y presión sistólica y diastólica cardiacas (Figura $1 \mathrm{~A}){ }^{2 \cdot-7}$ Estas catecolaminas son liberadas en situaciones de ira, estrés o ansiedad y por reacciones alérgicas 0 de hipotensión, mediadas por hormonas como la histamina, angiotensina II y bradicinina; ${ }^{1}$ ejercen sus efectos mediante la unión a los receptores adrenérgicos 0 adrenorreceptores (Figuras 1B y 1C). Estos se encuentran distribuidos en el sistema nervioso central y autónomo, así como en tejidos periféricos tales como el músculo radial del iris en el ojo, la piel y mucosas de los vasos sanguíneos en el corazón, trígono, esfínter de la vejiga, músculos obturador y esquelético, médula suprarrenal, hipófisis, glándula pineal y órganos sexuales masculinos, entre otros. ${ }^{2-7}$ La importancia de estos mediadores químicos es tal que la alteración en la síntesis y liberación de las catecolaminas - que normalmente circulan en la sangre en el orden de nanomoles 1 - o en la forma en que generan una respuesta celular al unirse a sus receptores específicos ${ }^{8}$ puede dar lugar a hiperplasia cardiaca y prostática, hipertrofia cardiaca, hipertensión o cáncer. ${ }^{2}$

Los adrenorreceptores localizados en la membrana plasmática de las células se activan por la unión de ambas catecolaminas y generan respuestas celulares específicas mediante varias vías deseñalización en las que participan elementos como las proteínas $G$ heterotriméricas, enzimas membranales como la fosfolipasa $C$ y adenil ciclasa (AC), que producen moléculas conocidas como "segundos mensajeros" y que al difundirse en la célula activan proteínas citosólicas como las cinasas, proteínas que transfieren grupos fosfato a residuos de aminoácidos específicos de las proteínas blanco, tales como los factores de transcripción (Figura 1B). De esta manera, y en un orden específico de activación, las proteínas que participan amplifican la señal extracelular modulando la expresión de genes relacionados con las distintas respuestas celulares (Figura 1B). ${ }^{8}$

La unión del agonista (ADRE y NA) a sus receptores específicos induce un cambio de conformación que promueve que estos interaccionen y recluten distintos elementos de la vía de señalización mediante una plataforma o proteína de andamio conocida como AKAP (A kinase anchoring protein), a la cual se suman más componentes dando lugar a un complejo multiproteico de señalización (Figura 2A). ${ }^{9-20}$ La AKAP contiene en su estructura varios dominios específicos de interacción proteína-proteína (Figura 2B), con los que por afinidad recluta a los elementos que participan en la regulación del receptor (Tabla 1) como cinasas y fosfatasas, que mantienen en equilibrio su estado de fosforilación, elementos que participan en su ubiquitinación y degradación, así como aquellos que participan en su internalización y en el tráfico vesicular (Figuras 2B y 2C). ${ }^{13-20}$

El conocimiento que se genere acerca de la composición de los complejos moleculares de la señalización adrenérgica, así como el estudio de los dominios de interacción de las proteínas que los componen, permitirá contar con blancos terapéuticos potenciales de las condiciones fisiopatológicas en las que participan estos receptores, como las enfermedades de origen cardiovascular, hipertrofia cardiaca, isquemia del miocardio, cardiomiopatía diabética y por desnutrición, cardiomiopatía dilatada y alteraciones congénitas. ${ }^{21-27}$

Aquí se describe brevemente la clasificación de los receptores adrenérgicos, sus características estructurales y vías de señalización. Se mencionan las proteínas más representativas del complejo de señalización del receptor $\beta_{2}$-adrenérgico, el prototipo de los receptores adrenérgicos, así como sus dominios de interacción. Se mencionan ejemplos de los complejos de señalización identificados en la fisiología normal y patológica del corazón. Finalmente, se hace referencia a herramientas metodológicas utilizadas en el estudio de las interacciones proteicas.

\section{Clasificación de los receptores adrenérgicos}

Con base en la farmacología y afinidad (dosis efectiva 50, $\mathrm{EC}_{50}$ ) que presentan los receptores adrenérgicos a diversos fármacos y agentes sintéticos (agonistas 
A

C

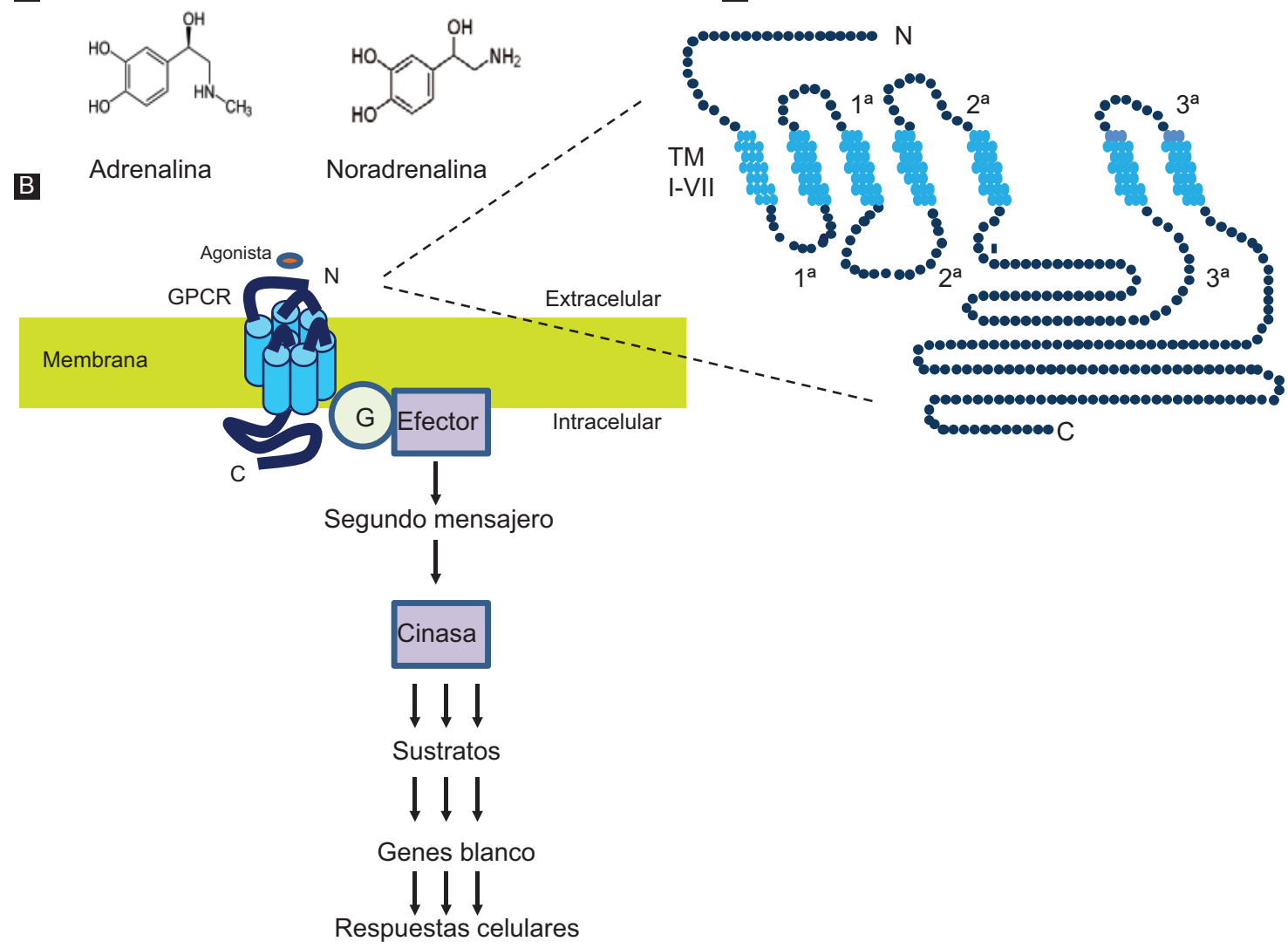

Figura 1. Sistema de señalización adrenérgico. Las catecolaminas: adrenalina (hormona) y noradrenalina (neurotransmisor) se unen a receptores blanco de siete dominios transmembranales conocidos como receptores acoplados a proteínas G (GPCR), los cuales constan, además, de tres asas extracelulares, tres asas intracelulares, el extremo amino extracelular $(N)$ y el extremo carboxilo intracelular $(C)$. El GPCR ( $\beta_{2}$-adrenérgico) localizado en la membrana plasmática al ser activado por el agonista se acopla a una proteína G heterotrimérica que activa a una proteína efectora en la membrana plasmática, la cual genera moléculas llamadas "segundos mensajeros" que se difunden en el citoplasma hasta activar cinasas de proteínas que amplifican la señal fosforilando a sus sustratos (factores de transcripción), lo cuales regulan la expresión de genes que participan en distintas respuestas celulares.

y antagonistas) se clasifican en tres grupos: $\beta, \alpha_{1}$ y $\alpha_{2}$, nomenclatura que se debe a la identidad en su secuencia primaria. ${ }^{2-5,8}$ Cada grupo tiene tres subtipos: $\beta_{1}, \beta_{2}, \beta_{3}, \alpha_{1 A}, \alpha_{1 B}, \alpha_{1 D}, \alpha_{2 A}, \alpha_{2 B} y \alpha_{2 C}$, todos productos de genes distintos (IUPHAR, International Union of Basic and Clinical Pharmacology). La primera clasificación fue hecha en 1948 por el farmacólogo Raymond Perry Ahlquist (1914-1983), quien dividió los receptores $\alpha$-adrenérgicos y $\beta$-adrenérgicos, con base en una serie de aminas simpaticomiméticas sobre una variedad de tejidos. Los receptores $\alpha$-adrenérgicos tienen efecto vasoconstrictor y producen excitación sobre el útero, corazón y vasos sanguíneos y solo tienen efecto de relajación en el intestino. Los receptores $\beta$-adrenérgicos tienen principalmente efecto vasodilatador y solo efecto vasoconstrictor en útero y excitador en el miocardio. ${ }^{28}$
En 1958, el trabajo de Earl Wilbur Sutherland (19151974), quien ganó el premio Nobel de Fisiología y Medicina en 1971, contribuyó a definir el mecanismo de acción de las hormonas. Sutherland y Ted Rall (1963) caracterizaron la función de los receptores empleando compuestos marcados radiactivamente, como el adenosín trifosfato $\left[8-^{14} \mathrm{C}\right] \mathrm{ATP}$. Observaron que el adenosín monofosfato cíclico (AMPc), que proviene de la ciclización del ATP, es un intermediario en la acción de hormonas como la ADRE, que actúa sobre la fosforilasa que participa en la formación de glucosa a partir de glucógeno. ${ }^{29}$ En 1967 se identificaron dos tipos de receptores $\beta$-adrenérgicos por su diferencia en la afinidad que presentan para la ADRE, que activa al subtipo $\beta_{2}$-adrenérgico con 100 veces más potencia que al $\beta_{1}$-adrenérgico. El subtipo $\beta_{3}$-adrenérgico fue descubierto más tarde y se consideró 


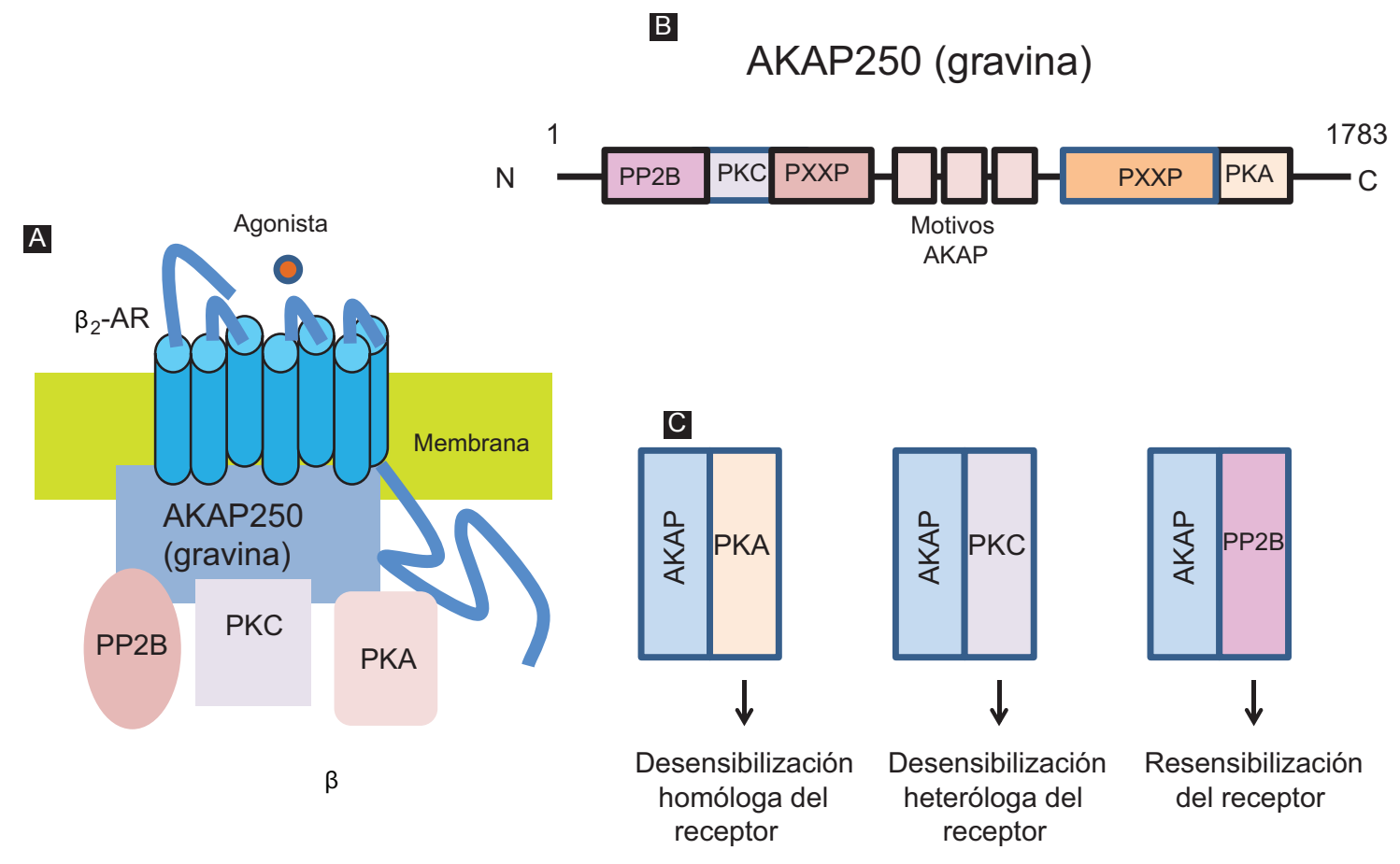

Figura 2. Complejo de señalización del receptor $\beta_{2}$-adrenérgico $\left(\beta_{2}-A R\right)$. La unión de la adrenalina al receptor $\beta_{2}$-AR incrementa su interacción la proteína de andamio (AKAP250/gravina/AKAP12), la cual recluta varios componentes de la vía de señalización (PKC, PKA, PP2B), que en conjunto modulan la función del receptor (desensibilización/resensibilización). AKAP250 tiene dominios de interacción proteína-proteína, entre ellos tres motivos AKAP conservados entre las AKAP, una región de interacción con F-actina hacia el $N$-terminal y dos regiones PXXP (prolina-X-X-prolina; $X=$ cualquier aminoácido) similares a dominios $\mathrm{SH} 3$ con el que interacciona con Src.

como "atípico", porque es insensible a los antagonistas $\beta_{1}$ y $\beta_{2}$ típicos. $^{7}$

Por otra parte, la clasificación de los receptores $\alpha_{1}$-adrenérgicos comenzó con el uso de la prazosina, un antagonista selectivo. ${ }^{2-4}$ Con el WB4101, otro antagonista, se identificaron claramente dos subtipos de $\alpha_{1}$-adrenérgicos: $\alpha_{1 \mathrm{~A}}$ y $\alpha_{1 \mathrm{~B}}$. El primer gen clonado fue el del receptor $\alpha_{1 B}$, más tarde se clonó el receptor $\alpha_{1 A}$-adrenérgico con el que hubo inicialmente controversia ya que se le había llamado previamente $\alpha_{1 C}$-adrenérgico $\left(\alpha_{1 A / C}\right)$. Posteriormente se identificó y clonó el receptor $\alpha_{1 D}$-adrenérgico $\left(\alpha_{1 A / D}\right),{ }^{2}$ quedando finalmente la nomenclatura $\alpha_{1 \mathrm{~A}}, \alpha_{1 \mathrm{~B}} \mathrm{y} \alpha_{1 \mathrm{D}}$. Por otra parte, con la yohimbina, un antagonista, se identificó el grupo de receptores $\alpha_{2}$-adrenérgicos, ${ }^{30}$ de los que se identificaron dos subtipos: $\alpha_{2 B}$ y $\alpha_{2 C}$, caracterizados con agonistas y antagonistas en ensayos funcionales y bioquímicos de unión de ligandos radiactivos al receptor conocidos como binding. ${ }^{3-6}$

Actualmente se estudia la importancia de cada subtipo de receptor adrenérgico en la fisiología humana, la caracterización de los elementos que participan en sus vías de señalización y su regulación bioquímica y molecular.

\section{Características de los receptores adrenérgicos}

Los receptores adrenérgicos pertenecen a la superfamilia de receptores acoplados a proteínas $G$ o GPCR ( $G$ protein-coupled receptors). Están conformados por siete regiones hidrofóbicas o hélices transmembranales (TM), tres asas extracelulares importantes para la unión del ligando y tres asas intracelulares, así como un extremo amino que es extracelular y un extremo carboxilo que se encuentra hacia el interior de la célula (Figura 1C). Se les llama adrenorreceptores presinápticos si se expresan en las neuronas simpáticas y adrenorreceptores postsinápticos si se expresan en las neuronas postsinápticas. ${ }^{3,4}$ Su expresión en los tejidos u órganos blanco es tejido/órgano-específica. ${ }^{2}$

Los receptores adrenérgicos responden a cambios en el ambiente y, por lo tanto, a una condición fisiológica determinada, como el incremento en la concentración de ADRE y NA en la circulación sanguínea. ${ }^{1}$ La unión del agonista al receptor induce en él un cambio de conformación que le permite acoplarse a la proteína G heterotrimérica, que al activarse intercambia guanosín 
difosfato (GDP), unido a la subunidad $\alpha$ en su estado inactivo por guanosín trifosfato (GTP). La liberación de GDP permite la disociación de la subunidad $\alpha$, que tiene GTP, del dímero $\beta \gamma$. La hidrólisis de GTP a GDP por la subunidad $\alpha$ (que tiene actividad de GTPasa) permite que las subunidades $\alpha$ y $\beta \gamma$ se asocien; el ciclo de activación/desactivación de la proteína G se inicia nuevamente al activarse el receptor. ${ }^{8}$

Son cuatro las familias de proteínas $G$ heterotriméricas: $G_{s}$ (estimulatoria), $G_{i}$ (inhibitoria), $G_{q / 11}$ y $G_{12 / 13^{*}}{ }^{8,26}$ Como consecuencia de la activación de la proteína $G$ $\left(G_{\mathrm{q} / 11}\right.$ y $\left.G_{s}\right)$ se activan enzimas efectoras de la membrana plasmática como la fosfolipasa $C$ que produce inositol 1,4,5-trisfosfato $\left(\mathrm{IP}_{3}\right)$ y 1,2-diacilglicerol (DAG), con lo que se observa liberación de iones de calcio del retículo endoplásmico y la AC que produce AMPc. ${ }^{8}$ Estos "segundos mensajeros" (IP ${ }_{3}$, DAG, calcio y AMPc) activan proteínas amplificadoras de la señal extracelular como la proteína cinasa dependiente de calcio (PKC) y la cinasa dependiente de AMPc (PKA) ${ }^{8}$ (Figura 1B). Por su parte, al desfosforilar sus sustratos por hidrólisis de los enlaces monoéster de los grupos fosfato, las proteínas fosfatasas regulan la amplificación de la señal extracelular. ${ }^{31}$

La investigación desarrollada por Robert J. Lefkowitz y Brian K. Kobilka de las Universidades de Duke y Stanford en Estados Unidos acerca de la estructura de los GPCR, así como de la regulación de la función de esta superfamilia de receptores, los llevó a obtener el premio Nobel de Química en 2012. ${ }^{32}$ Los hallazgos obtenidos durante cuatro décadas por estos dos grupos de investigación han abierto brecha hacia uno de los objetivos más importantes de la medicina: el diseño de fármacos específicos (agonistas y antagonistas) para los numerosos GPCR involucrados en distintas enfermedades. En la actualidad se han cristalizado aproximadamente 30 GPCR, entre los que destacan el receptor $\beta_{2}$-adrenérgico, tanto en estado inactivo ${ }^{33}$ como activo, ${ }^{34}$ el receptor muscarínico $\mathrm{M} 3,{ }^{35}$ el $\delta$-opioide ${ }^{36}$ y la rodopsina (receptor de la luz). ${ }^{37} \mathrm{El}$ análisis de difracción de rayos $X$ de los cristales de los GPCR y el modelaje de proteínas con programas computacionales proporcionan las estructuras de los receptores a nivel atómico, de tal forma que se puede estudiar con mayor detalle y precisión la función, forma de regulación, los sitios de unión de los ligandos y los dominios de interacción con proteínas.

\section{Complejos de señalización adrenérgicos}

En la transducción de señales (paso de una señal extracelular a una señalización intracelular mediada por receptores) (Figuras $1 \mathrm{~A}$ y $3 \mathrm{~A}$ ), la formación dinámica de complejos multiproteicos es clave para que la respuesta celular sea específica, eficiente y rápida (Figura $2 \mathrm{~A}$ ) ${ }^{38,39}$ Existen complejos preformados en ausencia del estímulo, debido a la difusión simple de las proteínas citoplásmicas y a su encuentro azaroso. ${ }^{40}$ Recientemente se ha sugerido que los complejos multiproteicos constitutivos se ensamblan durante la biosíntesis de las proteínas ${ }^{41} \mathrm{La}$ interacción requiere regiones afines entre sí, es decir, de dominios de interacción proteína-proteína. Algunos dominios descritos son los dominios homólogos a la cinasa de residuos de tirosina $\mathrm{Src}$ (Rous sarcoma virus): $\mathrm{SH} 4$ dominio único de $\mathrm{Src}, \mathrm{SH} 1$ que es el centro catalítico de las tirosincinasas, $\mathrm{SH} 2$ que se ancla a residuos de fosfotirosina y $\mathrm{SH} 3$, sitio de unión a la poliprolina. ${ }^{42-44}$ Otros como PTB (p-Tyr-binding) se unen a fosfotirosinas; $\mathrm{PH}$ (pleckstrin homology) es sitio de unión a fosfoinosítidos; $\mathrm{MH} 2$ (N-terminal DNA binding), sitio que reconoce y se une a la secuencia pSer-X-pSer; ${ }^{40}$ y PDZ (PSD-95, Dlg y ZO-1, siglas de las tres proteínas donde se identificó inicialmente), sitio que reconoce cuatro residuos hacia el carboxilo terminal de las proteínas blanco, ${ }^{45}$ entre otros. En particular, los dominios de interacción de algunos de los elementos del complejo de señalización adrenérgico son regiones polibásicas y regiones hidrofóbicas (Tabla 1).

El complejo de señalización del receptor $\beta_{2}$-adrenérgico es el mejor caracterizado. ${ }^{14-16}$ En respuesta al agonista, el receptor $\beta_{2}$ interacciona con la proteína de andamio AKAP250, también llamada gravina o AKAP12, a través de la cual recluta proteínas que participan en la respuesta $\beta_{2}$-adrenérgica (Figura 2A). ${ }^{46}$ Por ejemplo, las GRK2/3 ( $G$ protein-coupled receptor kinases 2 and $3)$, cinasas específicas que fosforilan residuos de serina o treonina de asas intracelulares o del extremo carboxilo del receptor, fosfatos que son reconocidos por proteínas de la maquinaria endocítica ( $\beta$-arrestina, AP2, clatrina) y lo internalizan en endosomas tempranos, con lo que se desencadena el proceso de desensibilización homóloga (pérdida de respuesta del receptor por la acción prolongada del agonista) 11,13,15,17 (Figura 3A). Igualmente, otras cinasas (PKA y PKC) pueden formar parte del complejo (Figura 2A), participando en la desensibilización heteróloga (pérdida de respuesta del receptor debida a estímulos distintos al agonista endógeno). ${ }^{47}$ Otras proteínas del complejo son las fosfatasas PP1, PP2A y PP2B (Figura 2A), que además participan en el proceso de "resensibilización", ya que el receptor internalizado regresa a la membrana plasmática sin fosfatos, donde puede ser activado nuevamente por el 
A
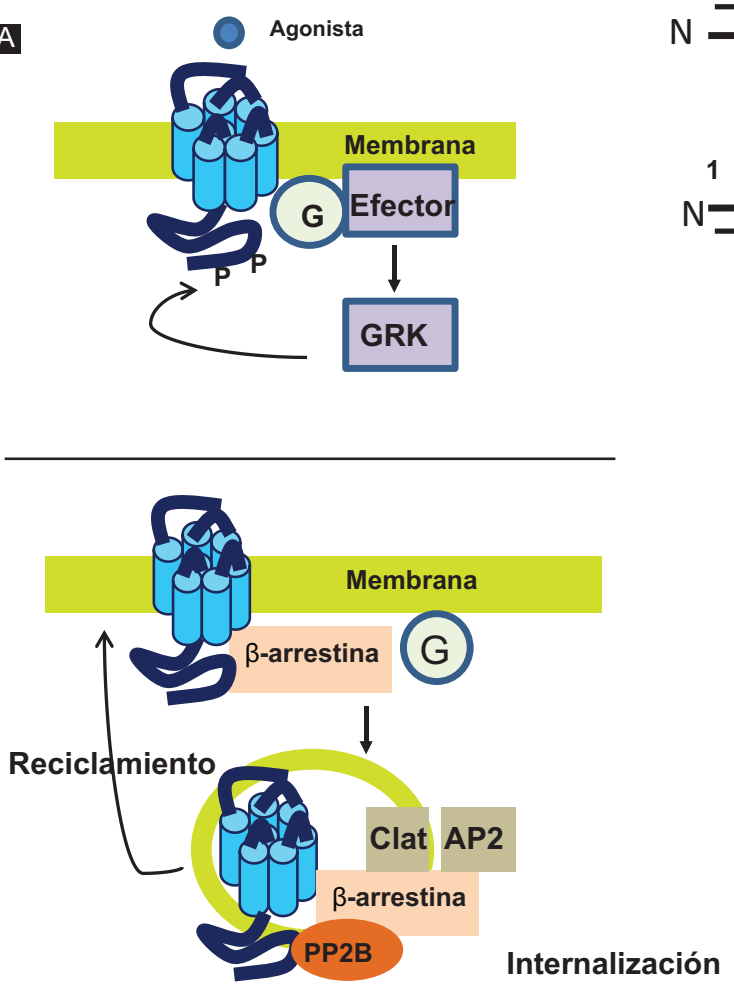

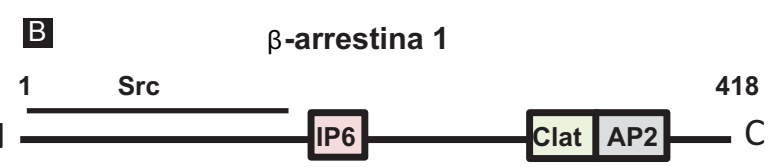

$\beta$-arrestina 2

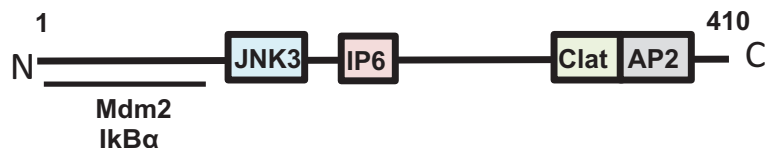

C
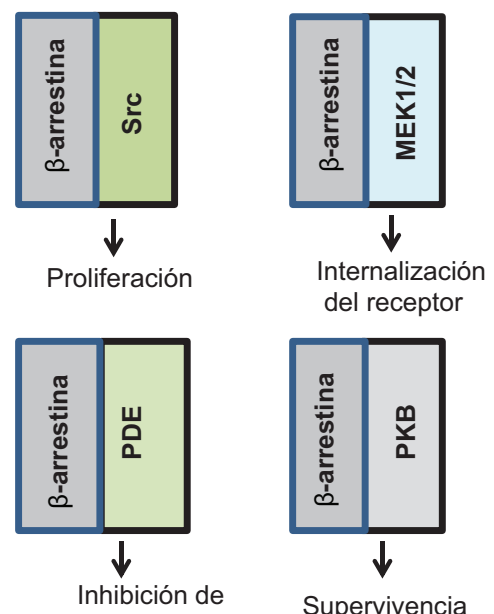

la vía de la MAPK

Figura 3. Interacción GPCR- $\beta$-arrestina. La unión del agonista al $\beta 2-A R$ induce, entre otros efectos, la activación de GRK que fosforila al receptor. La fosforilación del GPCR lo hace más afín a la interacción con la $\beta$-arrestina, una proteína adaptadora versátil. Por una parte, interfiere con el acoplamiento $\beta 2-A R$-proteína $G$ y, por otro, recluta proteínas que participan en la internalización y tráfico del receptor, así como elementos de la vía de las MAPK. La $\beta$-arrestina tiene una estructura modular, en el $\mathrm{N}$-terminal se encuentra el sitio de interacción con el receptor, tiene dos dominios reguladores, uno es el sitio de reconocimiento de la clatrina (Clat) y otro para la adaptina 2 (AP2). $\beta$-arrestina 1 tiene en el $N$-terminal uno o más dominios PXXP de reconocimiento para Src y JNK3 y en el C-terminal para NSF. $\beta$-arrestina 2 tiene un sitio de unión de JNK3 y de Mdm2.

ligando (Figura $3 \mathrm{~A}) .^{48}$ Src también puede formar parte del complejo (Figura 4) y participar tanto en la internalización como en el reciclamiento del receptor o como un modulador de la respuesta adrenérgica, vía receptores para factores de crecimiento. ${ }^{49}$

Algunas proteínas que forman parte del complejo de señalización no se unen a la AKAP, interaccionan directamente con el receptor o con proteínas adaptadoras, como la fosfodiesterasa de AMPc (PDE4) que disminuye los niveles del AMPc al degradarlo, ${ }^{50} \mathrm{AP}-2$ (adaptor protein 2), clatrina y $\beta$-arrestina, que participan en el tráfico del receptor, ${ }^{51}$ cinasas de la familia de la MAPK (mitogen activated protein kinase) como ERK1/2 (extracellular stimuli response kinase 1 and $2)^{52}$ y la ligasa de ubiquitina Mdm2 (murine double minute 2), que participa en la degradación del receptor. ${ }^{53}$ (Figuras $3 \mathrm{~A}$ y $3 \mathrm{C}$ ). Es importante mencionar que el receptor $\beta_{2}$-adrenérgico puede formar oligómeros con otros GPCR, interacciones que tienen repercusión funcional. Por ejemplo, el receptor $\beta_{2}$ internalizado en forma de homodímero es más estable a la degradación. ${ }^{54,55}$ Por otro lado, la acción $\beta_{2}$ adrenérgica sobre respuestas como la formación de hueso es regulada negativamente por el receptor de canabinoides tipo I (CBR1), ${ }^{56}$ receptor con el que forma heterodímeros. ${ }^{56,57}$ (Tabla 2) A la fecha, se han descrito al menos 20 proteínas que forman parte del signalosoma $\beta$-adrenérgico. Se conocen cinco proteínas que interaccionan con el receptor $\alpha_{2}$ y 8 con el receptor $\alpha_{1}$ (Tablas 2 y 3).

\section{Características estructurales del receptor, proteínas de andamio y adaptadoras del complejo de señalización adrenérgico}

Los dominios de interacción proteína-proteína del receptor, proteínas adaptadoras ( $\beta$-arrestina) y andamios (AKAP) que constituyen el complejo de señalización adrenérgico han sido ampliamente estudiados. 


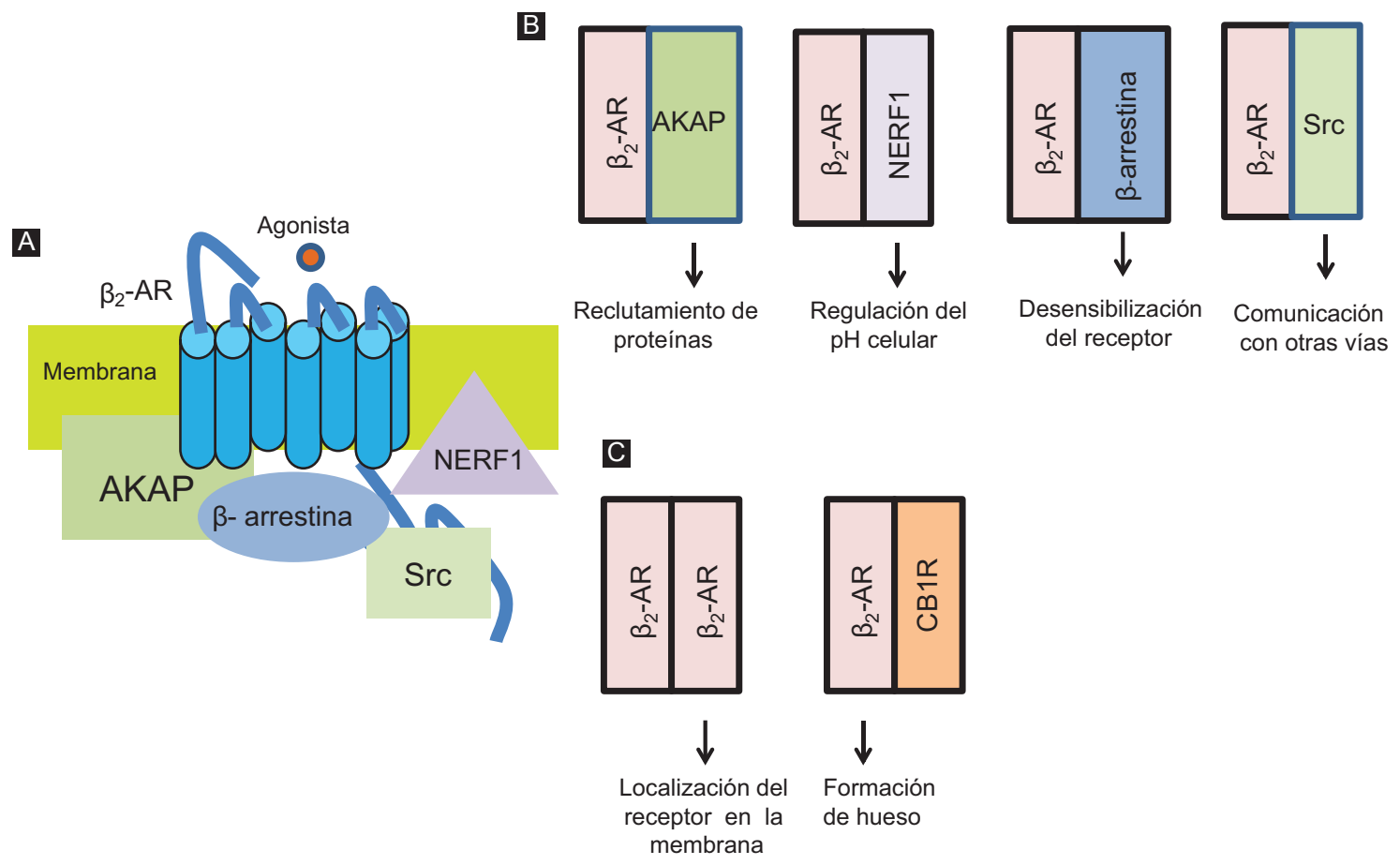

Figura 4. Interacción del $\beta_{2}-A R$ con proteínas adaptadoras, andamios y GPCR. El $\beta_{2}$-AR tiene dominios de interacción proteína-proteína para la $\beta$-arrestina, proteínas de andamio (AKAP), Src y el transportador $\mathrm{Na}^{+} / \mathrm{H}^{+}(\mathrm{NERF} 1)$ entre otras, así modula distintas respuestas celulares. El $\beta_{2}-A R$ puede formar dímeros y heterodímeros, interacciones que repercuten en su función.

\section{Receptores adrenérgicos}

Las interacciones canónicas del receptor $\beta_{2}$-adrenérgico con la proteína Gs y la $\beta$-arrestina, así como las interacciones entre dos receptores, se han descrito recientemente con el apoyo de la cristalografía de rayos $\mathrm{X}$ y con la adquisición de datos de difracción de los cristales, ya que permite ver su estructura con alta resolución. ${ }^{34} \mathrm{El}$ co-cristal receptor $\beta_{2}$-proteína Gs muestra que la superficie de contacto entre las dos proteínas (interface) involucra aminoácidos de las TM $\mathrm{V}$ y VI del receptor. Mientras que en la interface receptor- $\beta$-arrestina participa la tercera asa intracelular y la TM V, además, para que esta interacción sea de mayor afinidad se requiere la fosforilación por GRK, tanto de la tercera asa intracelular como del extremo carboxilo del receptor. ${ }^{34}$ Por otra parte, en la interface del homodímero del receptor $\beta_{2}$-adrenérgico participan las TM I, II, IV y V ${ }^{34,58}$ (Figura 1B).

El análisis bioquímico de la interacción "receptor-AKAP" muestra que en esta asociación participan dominios tipo PDZ de los cuales hay varias clases con la secuencia consenso X-[Ser/Thr]-X-[Val//le/lle], donde $X$ es cualquier aminoácido..$^{45}$ Se han caracterizado diferentes dominios PDZ en los receptores adrenérgicos como secuencias pequeñas glutámico-serina-lisina-valina (ESKV) en el carboxilo terminal del receptor $\beta_{1}$-adrenérgico; aspártico-serina-leucina-leucina (DSLL) en el $\beta_{2}$-adrenérgico y glutámico-aspártico-treonina-isoleucina (EDTI) en el $\alpha_{10}$-adrenérgico. A estos dominios se unen numerosas proteínas que tienen dominios PDZ, como canales de potasio y endofilina ${ }^{2,14}$ (Tabla 3).

\section{$\beta$-arrestina}

La $\beta$-arrestina fue identificada por el grupo de Robert Lefkowitz como una proteína similar a la arrestina visual que participa en la adaptación a la luz en el sistema de la rodopsina. Esta proteína se conoció por mucho tiempo como el freno de la transducción de señales de los GPCR porque interfiere físicamente con el acoplamiento entre el receptor y la proteína Gs (Figura $3 \mathrm{~A}){ }^{59,60}$ Sin embargo, el mismo grupo observó que la $\beta$-arrestina es capaz también de asociarse con otras proteínas durante la desensibilización, funcionando como una proteína adaptadora que recluta la maquinaria endocítica. ${ }^{61}$ Puede, además, interaccionar con otras $\beta$-arrestinas formando homo y heterodímeros 
Gaceta Médica de México. 2018;154

Tabla 1. Dominios de interacción proteína-proteína de algunos de los elementos que conforman el signalosoma $\beta_{2}$-adrenérgico

\begin{tabular}{|c|c|c|c|c|}
\hline Proteína & Dominio de interacción & $\begin{array}{l}\text { Localización del } \\
\text { dominio }\end{array}$ & Proteína con la que interactúa & Función \\
\hline AKAP & Hélice anfipática & $\mathrm{N}$-terminal & PKA & Amplificación de la señal \\
\hline \multirow[t]{3}{*}{ AKAP79 } & $\begin{array}{l}\text { Dominios polibásicos: 31-52, 77-101, } \\
\text { 116-145 aminoácidos }\end{array}$ & N-terminal & $\begin{array}{l}\text { PKC, CaM, F-actina } \\
\text { Caderina, AC5 }\end{array}$ & $\begin{array}{l}\text { Recluta elementos que } \\
\text { participan en la vía del GPCR }\end{array}$ \\
\hline & $315-360$ & C-terminal & PP2B & Término de la señal \\
\hline & $392-413$ & & PKA & Amplificación de la señal \\
\hline AKAP250 & $\begin{array}{l}18 \text { aminoácidos que forman una hélice } \\
\text { anfipática con residuos hidrofóbicos }\end{array}$ & N-terminal & PKA & Amplificación de la señal \\
\hline \multirow[t]{3}{*}{ GRK2 } & $\alpha-\mathrm{D}$ hélice; asas $\alpha-\mathrm{F}$ y $\alpha-\mathrm{G}$ & $\mathrm{N}$-terminal & GPCR & $\begin{array}{l}\text { Fosforilación del GPCR e } \\
\text { inhibición de la señal }\end{array}$ \\
\hline & & $\mathrm{N}$-terminal & Dímero Gby & Inactivación de $\mathrm{G} \alpha$ \\
\hline & & $\mathrm{N}$-terminal & MEK, PKB, ezrina, PI3K $\gamma$, GIT & Migración \\
\hline$\beta$-arrestina & & & Mdm2, MAPK; Src & Degradación de GRK2 \\
\hline $\begin{array}{l}\text { Proteína } \\
\mathrm{G} \alpha\end{array}$ & $\alpha-N$ hélice & N-terminal & $\begin{array}{l}\text { GPCR, dímero by y } \\
\text { efectores (fosfolipasa C) }\end{array}$ & Señalización \\
\hline GPCR & & $\begin{array}{l}\text { Asas intracelulares y } \\
\text { C-terminal }\end{array}$ & Proteína G, $\beta$-arrestina, GRK2 & $\begin{array}{l}\text { Señalización y } \\
\text { desensibilización }\end{array}$ \\
\hline
\end{tabular}

CAM, calmodulina; MEK, MAPK cinasa; PKB, proteína cinasa B; PI3K, fosfoinositol 3-cinasa; GIT, interactor cinasa del receptor acoplado a proteína G ${ }^{14,16,45}$

(Figuras 3B y $3 C$ ). Las dos isoformas de la $\beta$-arrestina tienen en el extremo amino un núcleo polar con aproximadamente 12 aminoácidos que reconoce al GPCR fosforilado. ${ }^{62,63}$ En esta misma región, la $\beta$-arrestina 2 tiene el sitio de interacción con cinasas de la familia de las MAPK como JNK3 (c-Jun N-terminal kinase 3), relevantes para la proliferación celular, respuesta al estrés y la supervivencia, así como el sitio de unión de Mdm2 y del inhibidor del factor de transcripción potenciador de las cadenas $k$ de las células $B$ activadas (I$\mathrm{kB})^{62,63}$ (Figura 3B) y en el extremo carboxilo de ambas $\beta$-arrestinas, los dominios de unión de clatrina y AP2 (Figura 3B). Se ha demostrado que la $\beta$-arrestina puede interactuar con más proteínas y de esta forma regular varias respuestas celulares (Figura $3 \mathrm{C}$ ).

\section{AKAP (A kinase anchoring-protein)}

Existen cerca de 70 proteínas de andamio (AKAP), cuyo nombre se deriva principalmente de su interacción con la PKA, específicamente con las subunidades reguladoras RII. Se expresan principalmente en la membrana plasmática ${ }^{9,10,11,16,17}$ pero su localización se extiende a otros compartimentos celulares..$^{20}$ Los residuos 1-107 de la AKAP5 (AKAP79/150) y los residuos 1-912 de la AKAP250 son importantes para la interacción con el GPCR, ambas son proteínas de andamiaje de la respuesta $\beta_{2}$-adrenérgica. ${ }^{64} \mathrm{En}$ el extremo amino de AKAP5 se identificaron los sitios de interacción con Src, cinasa involucrada en el reciclaje del receptor $\beta_{2}$-adrenérgico hacia la membrana plasmática, los sitios de PKC, PP1 y PP2B y hacia el carboxilo terminal y los sitios de PKA y de AKAP250 con la que forma hetero oligómeros. ${ }^{65}$

En el extremo amino de la AKAP250 se identificó una región anfipática llamada sitio RBD (receptor binding domain), que funciona en el reconocimiento y unión al GPCR, así como cuatro dominios que le permiten anclarse a la membrana plasmática: un sitio de $\mathrm{N}$-miristoilación y tres dominios pequeños cargados positivamente llamados PCD (small positively-charged domains), que se unen electrostáticamente a la cara interna de la membrana plasmática ${ }^{16}$ (Tabla 1).

\section{Importancia de los complejos de señalización adrenérgicos en la clínica}

Algunas fisiopatologías de origen cardiovascular, como la hipertrofia cardiaca e isquemia del miocardio, entre otros problemas graves de salud en el mundo, se relacionan con la acción adrenérgica. El corazón expresa todos los subtipos de receptores adrenérgicos 
Tabla 2. Oligómeros de los receptores adrenérgicos. Se indica el papel de la interacción en la internalización y su efecto sobre distintas respuestas celulares

\begin{tabular}{|c|c|c|c|}
\hline Receptor adrenérgico & Oligomerización & Internalización & Efecto celular \\
\hline$\beta_{1}$ & $\beta_{2}$ & No permite internalización del $\beta_{2}$ & Disminuye la activación de ERK \\
\hline$\beta_{2}$ & $\beta_{2}$ & Sí & Internalización más estable \\
\hline$\beta_{2}$ & $\beta_{3}$ & No permite internalización del $\beta_{2}$ & No acoplamiento con Gi \\
\hline$\beta_{2}$ & olfatorio & $\begin{array}{l}\text { Expresión del receptor olfatorio en la } \\
\text { membrana y cointernalización }\end{array}$ & No se conoce \\
\hline$\beta_{2}$ & Opioide $\delta$ & Cointernalización & No se conoce \\
\hline$\beta_{2}$ & Opioide k & No permite internalización del $\beta_{2}$ & Endocitosis en respuesta a la insulina \\
\hline$\beta_{2}$ & $\begin{array}{l}\text { Angiotensina I } \\
\text { (AT1R) }\end{array}$ & $\begin{array}{l}\text { Inhibición de la internalización por } \\
\text { antagonistas del AT1R }\end{array}$ & Corrientes de calcio \\
\hline$\beta_{2}$ & $\begin{array}{l}\text { Serotonina } \\
(5 \mathrm{HT} 4)\end{array}$ & No se conoce & Corriente de potasio \\
\hline$\beta_{2}$ & $\begin{array}{l}\text { Canabinoide I } \\
\text { (CB1R) }\end{array}$ & $\begin{array}{l}\text { Internalización constitutiva del CB1R/ } \\
\text { cointernalización }\end{array}$ & $\begin{array}{l}\text { Analgesia/inhibición de la formación de hueso por acción } \\
\text { adrenérgica }\end{array}$ \\
\hline$\alpha_{1 \mathrm{~A}}$ & $\alpha_{1 \mathrm{~A}}$ & No & No se conoce \\
\hline$\alpha_{1 \mathrm{~A}}$ & $\alpha_{1 B}$ & Cointernalización & No se conoce \\
\hline$\alpha_{1 \mathrm{~B}}$ & $\alpha_{1 \mathrm{~B}}$ & No & No se conoce \\
\hline$\alpha_{1 \mathrm{~B}}$ & $\alpha_{1 \mathrm{D}}$ & Expresión del $\alpha_{1 D}$ en la membrana & Disminuye afinidad por ligandos $\alpha_{1 D}$ \\
\hline$\alpha_{1 \mathrm{D}}$ & $\beta_{2}$ & Cointernalización & Expresión del $\alpha_{1 D}$ en la membrana \\
\hline$\alpha_{2 A}$ & $\alpha_{2 C}$ & No se conoce & Incremento de la señalización \\
\hline$\alpha_{2 A}$ & $\beta_{1}$ & Cointernalización & Fosforilación del a2A \\
\hline$\alpha_{2 A}$ & Opioide $\mu$ & No se conoce & Incremento en la señalización de ambos receptores \\
\hline$\alpha_{2 A}$ & Opioide $\delta$ & No se conoce & Crecimiento de neuritas mediado por el receptor opioide $\delta$ \\
\hline$\alpha_{2 C}$ & $\beta_{2}$ & Expresión del $\alpha_{2 C}$ en la membrana & Aumenta la señalización de ERK mediada por el $\alpha_{2 C}$ \\
\hline
\end{tabular}

y varias isoformas de las AKAP, por lo que se considera un modelo muy importante para estudiar los mecanismos moleculares de la formación de complejos de señalización en la fisiología cardiaca normal y en condiciones fisiopatológicas con la esperanza de descubrir blancos terapéuticos que ayuden al tratamiento de las enfermedades. Se ha descrito que los cardiomiocitos expresan los receptores $\beta_{1}$ y $\beta_{2}$-adrenérgicos en regiones de la membrana plasmática enriquecidas con colesterol y otros lípidos (lipid rafts) y en caveolas que contienen caveolina forman invaginaciones; el subtipo $\beta_{1}$, además, se localiza en regiones que no contienen colesterol, incluso en la membrana nuclear, mientras que el subtipo $\beta_{3}$ no se ha observado en la membrana plasmática, pero sí en la nuclear, junto con el subtipo $\beta_{1}$. Estas células también expresan en las membranas plasmática y nuclear a los receptores $\alpha_{1 \mathrm{~A}}$ y $\alpha_{1 \mathrm{~B}}$-adrenérgicos. 10,14,66,67
Como se mencionó, el corazón expresa varias AKAP que funcionan como integradores de la señalización adrenérgica: mAKAP, AKAP18, AKAP79, D-AKAP1/2, AKAP95, AKAP220, AKAP-LBC, AKAP250/gravina, ezrina, yotiao, sinemina, SPHKAP y BIG2. ${ }^{12,15,21,22} \mathrm{En}$ la contracción del músculo cardiaco durante cada latido, la activación de los receptores $\beta_{1}$ y $\beta_{2}$-adrenérgicos por las catecolaminas liberadas de la inervación simpática, incrementa la cinética del ciclo excitación-contracción, donde la corriente eléctrica se convierte en una fuerza mecánica que resulta en un ciclo rítmico del incremento de calcio entre el citosol y el retículo sarcoplásmico (RS), eventos en los que participa un gran número de proteínas reclutadas por AKAP18. ${ }^{9}$ Los efectos cronotrópico e inotrópico positivos se generan principalmente mediante la vía clásica: proteína G-AMPc-PKA-fosforilación de la maquinaria contráctil y de proteínas accesorias tales como canales de 
Gaceta Médica de México. 2018;154

Tabla 3. Proteínas que interactúan directamente con los receptores adrenérgicos

\begin{tabular}{|c|c|c|c|}
\hline Receptor adrenérgico & Proteína de interacción & Sitio de interacción con el receptor & Efecto celular \\
\hline \multirow[t]{10}{*}{$\beta_{1}$} & Endofilinas & $\begin{array}{l}\text { Tercera asa intracelular (rica en } \\
\text { prolinas) }\end{array}$ & Endocitosis \\
\hline & PSD-95 & C-terminal (ESKV) & Endocitosis/Asociación con el receptor de NMDA \\
\hline & MAGI-2 & C-terminal (ESKV) & Endocitosis/asociación con $\beta$-catenina \\
\hline & GIPC & C-terminal (ESKV) & Inhibición de ERK \\
\hline & CAL & C-terminal (ESKV) & Disminuye la expresión en membrana \\
\hline & RasGEF & C-terminal (ESKV) & Activación de Ras \\
\hline & GASP & C-terminal (ESKV) & No se conoce \\
\hline & Golgin-160 & Tercera asa intracelular & Aumenta la expresión en membrana \\
\hline & $14-3-3$ & Sitios fosforilados & Regulación de canales de $\mathrm{K}^{+}$ \\
\hline & PDE4 & No se conoce & Regulación de los niveles de AMPc \\
\hline \multirow[t]{8}{*}{$\beta_{2}$} & AKAP 250 (gravina) & C-terminal & Endocitosis/desensibilización/resensibilización \\
\hline & AKAP79 & No se conoce & Asociación de GRK \\
\hline & AKAPLC & No se conoce & Corrientes de calcio \\
\hline & Grb2 & Tyr350/354 & Endocitosis en respuesta a la insulina \\
\hline & Cav1.2 & No se conoce & Corrientes de calcio \\
\hline & $\mathrm{BKCa}$ & No se conoce & Corriente de potasio \\
\hline & $\begin{array}{l}\text { pVHL } \\
\text { EGLN3 }\end{array}$ & Pro382/395 & Ubiquitinación en respuesta a oxígeno \\
\hline & NERF1 & C-terminal (DSLL) & Regulación del intercambiador $\mathrm{Na}^{+} / \mathrm{H}^{+}$ \\
\hline$\beta_{3}$ & Src & $\begin{array}{l}\text { Tercera asa intracelular y C-terminal } \\
\text { rico en prolina }\end{array}$ & Activación de ERK \\
\hline \multirow[t]{2}{*}{$\alpha_{1 A}$} & $\begin{array}{l}\text { Metaloproteinasa de } \\
\text { matriz }\end{array}$ & No se conoce & Expresión en la membrana \\
\hline & RGS2 & Tercera asa intracelular & Disminución Gq \\
\hline \multirow[t]{3}{*}{$\alpha_{1 \mathrm{~B}}$} & Espinofilina & Tercera asa intracelular & Reciclamiento \\
\hline & AP50 & C-terminal & Endocitosis \\
\hline & Ezrina & C-terminal & Reciclamiento \\
\hline$\alpha_{10}$ & Sintrofinas & C-terminal (ETDI) & Estabilización del receptor en la membrana \\
\hline$\alpha_{1 \mathrm{~A}, \mathrm{~B}, \mathrm{~B}, \mathrm{D}}$ & nNOS & No se conoce & No se conoce \\
\hline$\alpha_{1 \mathrm{~B}, \mathrm{D}-}$ & gC1qR & C-terminal (Arg) & Localización intracelular \\
\hline$\alpha_{2 A}$ & Uch-L1 & Tercera asa intracelular & Disminuye MAPK \\
\hline \multirow[t]{2}{*}{$\alpha_{2 A, B, C-}$} & Espinofilina & Tercera.asa intracelular & No se conoce \\
\hline & $14-3-3 z$ & Tercera asa intracelular & No se conoce \\
\hline
\end{tabular}

Se indica el sitio de interacción con el receptor y la función que tiene dicha interacción.

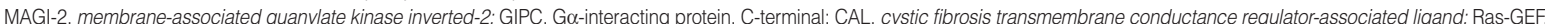

GTP exchange factor; GASP, G protein coupled receptor-associated protein; NERF1, $\mathrm{Na}^{+} / \mathrm{H}^{+}$exchanger regulatory factor; $\mathrm{nNOS}$, neuronal nitric oxid sintetase; Uch-L1, ubiquitin carboxy

terminal hydrolase-L1; BKCa, calcium activated potassium cannel; pVHL, the von Hippel-Lindau protein; RGS, regulator of G protein signaling; gC1qR, globular C1q-domain receptor.

En algunos casos aún no se conoce el sitio o la función de la interacción. Tabla modificada de referencia 2. 
calcio, receptor de rianodina, troponina-l y el fosfolambano. 12,15,68 En este ciclo, la contracción depende de calcio y se inicia con la entrada del catión a través de canales tipo-L, los cuales por su localización en el sarcolema actúan sobre receptores de rianodina (RR); el incremento de la concentración local de calcio en los alrededores de los RR es suficiente para activar la liberación de calcio inducida por calcio y vaciar los almacenes del RS. La robusta onda de calcio en el citosol permite al catión unirse a los microfilamentos, específicamente a la troponina C, y así iniciar la contracción del miocito. ${ }^{12,15,68}$

Se ha observado que la activación crónica de esta cascada da lugar a una progresiva disfunción cardiaca, hipertrofia e insuficiencia cardiaca. La actividad prolongada de PKA desregula algunas proteínas, incluyendo el receptor $\beta_{1}$ - adrenérgico, por lo que este se consideró el primer blanco terapéutico descrito en el tratamiento de estas afecciones, utilizando antagonistas para inhibir su función. Sin embargo, como estos fármacos producen efectos secundarios, el estudio y caracterización de los complejos de señalización cardiacos y de los dominios de interacción prometen identificar blancos más específicos. Por ejemplo, uno de estos blancos podría ser la interacción entre AKAP18 y el fosfolambano-ATPasa de calcio, ya que se demostró que péptidos sintéticos que compiten por la unión con AKAP disminuye $50 \%$ la acción $\beta$-adrenérgica. Otro posible blanco de la acción farmacológica es la interacción de la AKAP con las distintas fosfatasas (PP1, PP2A y PP2B), ${ }^{22}$ porque son moduladores del estado de fosforilación/activación de las proteínas del complejo durante la relajación del músculo cardiaco que requiere la remoción del calcio citosólico, capturado por el RS a través de la ATPasa dependiente de calcio y del intercambiador de $\mathrm{Na}^{+} / \mathrm{Ca}^{+2}$ y otros canales, con lo que se restaura el potencial de reposo. La inhibición de la ATPasa resulta en un efecto inotrópico y lusotrópico negativos, por otro lado, si se afecta la interacción AKAP-PKA, tanto in vivo como ex vivo, también se afecta negativamente la función normal del corazón, se altera la duración de los latidos (efecto cronotrópico) y la fuerza de los latidos (efecto inotrópico), así como la velocidad de relajación (efecto lusotrópico).

Otros complejos de señalización formados en respuesta a la acción $\beta_{2}$-adrenérgica e importantes para la fisiología del corazón son AKAP15-PKA-Ca 1.2 , AKAPLcb-PKA-PKC-PKD-Rho-14-3-3 y Yotiao-PKAKCNQ1-PDE4D-PP1. ${ }^{21,22}$ Se demostró experimentalmente que la conducta cardiaca se afecta por la ausencia de alguna de las proteínas que forman parte de los signalosomas por mutaciones puntuales o por inhibición de su expresión: la ausencia del canal de calcio dependiente de voltaje $\left(\mathrm{Ca}_{v} 1.2\right)$ induce un fenotipo de severa hipertrofia cardiaca y lleva a la muerte perinatal, ${ }^{21}$ la ausencia de AKAP-Lcb (AKAP13) induce el adelgazamiento del miocardio al inhibir el crecimiento celular, fenotipo letal de los embriones de ratón y, por último, la falta del canal de potasio KCNQ1 o de Yotiao (AKAP9) genera arritmias del corazón.

En arterias coronarias del epicardio de ratón se caracterizó un complejo integrado en respuesta a la activación del receptor $\alpha_{1 D}$-adrenérgico llamado DAPC (distrophyn-associated protein complex) que contiene distrofina y sintrofina; ${ }^{68}$ se relaciona con la distrofia muscular de Duchenne, en la que una mutación en el gen de la distrofina produce una proteína defectuosa que resulta en la degeneración progresiva de los músculos, afectando funciones cognitivas o cardiacas.

Aunque se han descrito complejos multiproteicos y su importancia funcional en algunas patologías cardiacas, como las mencionadas, otras enfermedades cardiacas de elevada incidencia, como la cardiomiopatía diabética, cardiomiopatía por desnutrición, cardiomiopatía dilatada y las alteraciones congénitas, aún requieren atención. El desarrollo de métodos experimentales nuevos ha apoyado sustancialmente estos estudios. ${ }^{69}$

\section{Métodos experimentales para el estudio de las interacciones proteína-proteína}

Algunos métodos bioquímicos y de biología molecular que se usan para el estudio de las interacciones proteicas son los siguientes:

- Sistema de doble híbrido: se basa en la presencia de dos dominios ( $A$ y $B$ ) de un factor de transcripción; se generan dos genotecas, una con los genes fusionados al dominio A y la otra al dominio B. Los plásmidos con estos genes se integran en levaduras y solo cuando interactúan proteínas de ambos conjuntos, los dos dominios del factor de transcripción se unen e inducen la expresión del "gen reportero" (LacZ) regulado por el factor y se detecta por la actividad de una enzima (beta-galactosidasa).

- FRET (fluorescence resonance energy transfer): técnica que se fundamenta en la excitación de un fluorocromo fusionado a una proteína que se transfiere a otro cercano $(10-100 \AA)$ y que se detecta como fluorescencia.

- BRET (bioluminiscence resonance energy transfer): monitorea las interacciones proteicas en 
tiempo real, se basa en la coexpresión heteróloga de dos proteínas de fusión, la primera fusionada a un donador bioluminiscente y la segunda a un fluoróforo aceptor; la transferencia de energía se puede detectar como fluorescencia del aceptor.

- Coinmunoprecipitación: se basa en la purificación de proteínas endógenas y en la detección de una o más proteínas asociadas por ensayos de Western blot usando anticuerpos específicos.

- Microscopia confocal: permite observar con alta resolución la colocalización de dos proteínas, una fusionada al fluoróforo $X=$ verde y la otra al fluoróforo $Y=$ rojo. Si las proteínas interaccionan, al sobreponer las dos imágenes se observa un color distinto al original, $\mathrm{Z}=$ amarillo, por la combinación de ambos.

- Espectrometría de masas: identifica masas peptídicas de una proteína purificada y fragmentada con enzimas, así como de las proteínas asociadas, comparando con las masas teóricas del conjunto de péptidos esperados para las secuencias almacenadas en una base de datos.

\section{Discusión}

La formación de complejos multiproteicos en los sistemas de transducción de señales de los GPCR, familia a la que pertenecen los receptores adrenérgicos, es clave en la organización de los elementos que participan en la vía de transducción en respuesta al estímulo extracelular, proporcionando especificidad espacio-temporal y rapidez en la respuesta. ${ }^{9-11,13,18,19}$ Son las proteínas que funcionan como un andamio (AKAP), el lugar en donde se reclutan cinasas, fosfatasas, fosfodiesterasas, canales iónicos y proteínas adaptadoras, entre otras, para regular la función de los receptores adrenérgicos y de muchos otros GPCR. El estudio de las AKAP permitió observar que la alteración de los complejos de señalización, específicamente el del receptor $\beta_{2}$-adrenérgico, representa un factor clave en el desarrollo de enfermedades cardiacas o de otros órganos donde se expresen y participen receptores adrenérgicos. El diseño de fármacos más específicos que modulen las interacciones entre los miembros de un complejo se visualiza como una estrategia terapéutica prometedora.

\section{Agradecimientos}

Al doctor Jesús Adolfo García Sáinz, investigador emérito de la Universidad Nacional Autónoma de
México, y al Instituto de Fisiología Celular de la misma Universidad.

\section{Bibliografía}

1. Lymperopoulos A, Brill A, McCrink KA. GPCRs of adrenal chromaffin cells and catecholamines: The plot thickens. Int J Biochem Cell Biol. 2016;77(Pt B):213-219.

2. Cotecchia $\mathrm{S}$. The $\alpha_{1}$-edrenergic receptors diversity of signaling networks and regulation. J Recept Signal Transduct Res. 2010;30(6):410-419.

3. Forster C. Agonistas de los adrenorreceptores. En: Kalant H, Roschlau WHE (eds.). Principios de farmacología médica. México: Oxford; 2003.

4. Forster $\mathrm{C}$. Antagonistas de los adrenorreceptores. En: Kalant H, Roschlau WHE, editores. Principios de farmacología médica. México: Oxford; 2003.

5. Mitchell J. Transducción de señales y segundos mensajeros. En: Kalant H, Roschlau WHE, editores. Principios de farmacología médica. México: Oxford; 2003.

6. Mycek MJ, Harvey RA, Champe PC. Agonistas adrenérgicos. En: Harvey RA, Champe PC, editors. Farmacología. México: McGrawHill; 2007.

7. Mycek MJ, Harvey RA, Champe PC. Antagonistas adrenérgicos. En: Harvey RA, Champe PC, editores. Farmacología. México: McGrawHill; 2007

8. García-Sáinz JA. Hormonas: mensajeros químicos y comunicación ceIular. México: Fondo de Cultura Económica; 2016.

9. Carniegie KM, Means CK, Scott JD. A-kinase anchoring proteins: from protein complexes to physiology and disease. IUBMB Life. 2009; 61(4):394-406.

10. Dombrádi V, Krieglstein J, Klumpp S. Regulating the regulators. EMBO Rep. 2002;3(2):120-124.

11. Groves JT, Kuriyan J. Molecular mechanisms in signal transduction at the membrane. Nat Struct Mol Biol. 2010;17(6):659-665.

12. Bauman AL, Michel JJ, Henson E, Dodge-Kafka KL, Kapiloff MS. The mAKAP signalosome and cardiac myocyte hypertrophy. IUBMB Life. 2007:59(3):163-169.

13. Pawson CT, Scott JD. Signal interaction through blending, bolstering and bifurcating of intracellularinformation. Nat StructMol Biol. 2010;17(6):653-658.

14. Cotecchia S, Stanasila L, Diviani D. Protein-protein interaction at adrenergic receptors. Curr Drug Targets. 2012;13(1):15-27.

15. Diviani D, Reggi E, Arambasic C, Caso S, Maric D. Emerging roles of A-kinase anchoring proteins in cardiovascular pathophysiology. Biochim Biophys Acta. 2016;18637(7 Pt B):1926-1936.

16. Malbon CC, Tao J, Wang HY. AKAPs (A-kinase anchoring proteins) and molecules that composes their G-protein-coupled receptor signaling complexes. Biochem J. 2004;379(Pt 1):1-9.

17. Logue JS, Scott JD. Organizing signal transduction through A-kinase Anchoring proteins (AKAPs). 2010;277(21):4370-4375.

18. Vázquez-Prado J, Casas-González P, García-Sáinz JA. G protein-coupled receptor cross-talk: pivotal roles of protein phosphorylation and protein-protein interactions. Cell Signal. 2003;15(6):549-557.

19. Tao J, Shumay E, McLaughlin S, Wang HY, Malbon CC. Regulation of AKAP-membrane interactions by calcium. J Biol Chem. 2006;281(33):23932-23944.

20. Perino A, Ghigo A, Scott JD, Hirsch E. Anchoring proteins as regulators of signaling pathways. Circ Res. 2012;111(4):482-492.

21. Fu Y, Westenbroek RE, Yu FH, Clark JP, Marshall MR, Scheuer T, et al. Deletion of the distal $C$ terminus of Cav1.2 channels leads to loss of $\beta$-adrenergic regulation and heart failure in vivo. $J$ Biol Chem. 2011;286(14):12617-12626.

22. Redden JM, Dodge-Kafka KL. AKAP phosphatases complexes in the heart. J Cardiovasc Pharmacol. 2011;58(4):354-362.

23. Shi T, Papay RS, Pérez DM. $\alpha_{1}$-adrenergic receptor prevents cardiac ischemic damage through PKC/GLUT1/4-mediated glucose uptake. J Recept Signal Transduct Res. 2016;36(3):261-270.

24. Östman-Smith I. Beta-blockers in pediatric hypertrophic cardiomyopathies. Rev Recent Clin Trials. 2014;9(2):82-85

25. Hamada M, Ikeda S, Shigematsu Y. Advances in medical treatment of hypertrophic cardiomyopathy. J Cardiol. 2014;64(1):1-10.

26. DeFilipps EM, Givertz MM. Treating diabetes in pacients with heart failure: moving from risk to benefit. Curr Heart Fail Rep. 2016;13(3):111-118.

27. Hinson JT, Chopra A, Nafissi N, Polacheck WJ, Benson CC, Swist S, et al. Titin mutations in iPS cells define sarcomere insufficiency as a cause of dilated cardiomyopathy. Science. 2015;349(6251):982-986.

28. Ahlquist RP. A study of adrenotropic receptors. Am J Physiol. 1948;153(3):586-600.

29. Sutherland EW, Rall TW. Fractionation and characterization of a cyclic adenine ribonucleotide formed by tissue particles. J Biol Chem. 1958;232(2):1077-1091.

30. Galitzky J, Vermorel M, Lafontan M, Mantastruc P, Berlan M. Termogenetic and lipolytic effect of yohimbine in the dog. Br J Pharmacol. 1991; 104(2):514-518 
31. Alcántara-Hernández R, Casas-González P, García-Sáinz JA. Signal transduction pathway cross-talk. Role of protein kinases, protein phosphatases and reactive oxygen species. Curr Trends Endocrinol. 2005;1:19-30.

32. García-Sáinz JA. Robert Lefkowitz y Brian Kobilka: premios Nobel 2012. Rev Fac Med UNAM. 2013;56(1):59-63.

33. Rasmussen SG, Choi HJ, Rosenbaum DM, Kobilka TS, Thian FS, Edwards PC, et. al. Crystal structure of the human $\beta 2$ adrenergic G-protein-coupled receptor. Nature. 2007;450(7168):383-388.

34. Rasmussen SG, DeVree BT, Zou Y, Kuse AC, Chung KY, Kobilka TS, et al. Crystal structure of the $\beta 2$ adrenergic receptor-Gs protein complex. Nature. 2011:477(7366):549-555.

35. Kruse AC, Hu J, Pan AC, Arlow DH, Rosenbaum DM, Rosemond E, et al. Structure and dynamics of the M3 muscarinic acetylcholine receptor Nature. 2012;482(7386):552-556.

36. Granier S, Manglik A, Kruse AC, Kobilka TS, Thian FS, Weiss WI, Kobilka BK. Structure of the d-opioid receptor bound to naltrindole. Nature. 2012;485(7398):400-404.

37. Okada T, Le Trong I, Fox BA, Behnke CA, Stenkamp RE, Palczewski K. $\mathrm{X}$-Ray diffraction analysis of the three-dimensional crystals of bovine rhodopsin obtained from mixed micelles. J Struct Biol. 2000; 130(1):73-80.

38. Pawson CT, Scott JD. Signal integration blending, bolstering and bifurcating of intracellular information. Nat Struct Mol Biol. 2010;17(6):653-658

39. Welch JEJ, Jones BW, Scott JD. Networking with AKAPs: context-dependent regulation of anchored enzymes. Mol Interv. 2010;10(2):86-97.

40. Zentella-Dehesa A, Alcántara-Hernández R. Importancia de los dominios de interacción proteica en la formación de complejos en los sistemas de transducción. Rev Educ Bioq. 2003;22(3):117-129.

41. Huber T, Sakmar TP. Escaping the flatlands: new approaches to study dynamic assembly and activation of GPCRs signaling complexes. Trends Pharmacol Sci. 2011;32(7):410-419.

42. Pawson T. Newimpressions of Srcand Hck. Nature. 1997:385(6617):582-609.

43. Roskoski R. Src protein-tyrosine kinase structure and regulation. Biochem Biophys Res Commun. 2004;324(4):1155-1164.

44. Foster-Barber A, Bishop JM. Src interact with dynamin and synapsin in neuronal cells. Proc Natl Acad Sci U S A. 1998;95(8):4673-4677.

45. Ponting CP, Phillips Ch, Davies KE, Blake DJ. PDZ domains: targeting signaling molecules to sub-membranous sites. Bioessays. 1997;19(6):469-479.

46. Tao J, Wang H-yu, Malbon CC. Protein kinase A regulates AKAP250 (gravin) scaffold binding to the $\beta_{2}$-adrenergic receptor. EMBO J. 2003;22(24):6419-6429.

47. Lin F, Wang HY, Malbon CC. Gravin-mediated formation of signaling complexes in beta 2-adrenergic receptor desensitization and resensitization. J Biol Chem. 2000;275(25):19025-19034.

48. García-Sáinz JA, Romero-Ávila T, Alcántara-Hernández R. Mechanisms involved in $\alpha_{1 B}$-adrenoceptor desensitization. IUBMB Life. 2011; 63(10):811-815.

49. Tao J, Wang HY, Malbon CC. Src docks to A-kinase anchoring protein gravin, regulating beta2-adrenergic receptor resensitization and recycling. J Biol Chem. 2007;282(9):6597-6608.

50. Willoughby D, Wong W, Shaack J, Scott JD, Cooper DM. An anchored PKA and PDE4 complex regulates subplasmalemmal cAMP dynamics. EMBO J. 2006;25(10):2051-2061.

51. Laporte SA, Oakley RH, Holt JA, Barak LS, Caron MG. The interaction of beta-arrestin with AP-2 adaptor is required for the clustering of beta2-adrenergic receptor into clathrin-coated pits. J Biol Chem. 2000;275(30):23120-23126.
52. Azzi M, Charest PG, Rousseau G, Kohout T, Bouvier M, Piñeyro G, et al. $\beta$-arrestin-mediated activation of MAPK by inverse agonists revels distinct active conformations for $\mathrm{G}$ protein-coupled receptors. Proc Natl Acad Sci U S A. 2003;100(20):11406-11411.

53. Shenoy SK, Xiao K, Weissman AM, Venkataramanan V, Snyder PM, Freedman NJ. Nedd4 mediates agonist-dependent ubiquitination, lysosomal targeting, and degradation of the b2-adrenergic receptor. J Biol Chem. 2008:283(32):22166-22176.

54. Wnorowski A, Jozwiak K. Homo- and hetero-oligomerization of $\beta_{2}$-adrenergic receptor in receptor trafficking, signaling pathways and receptor pharmacology. Cell Signal. 2014;26(10):2259-2265.

55. Salahpour A, Angers S, Mercier JF, Lagacé M, Marullo S, Bouvier M. Homodimerization of the beta2-adrenergic receptor as a prerequisite for cell surface targeting. J Biol Chem. 2004;279(32):33390-33397.

56. Tam J, Trembovier V, DiMarzo V, Petrosino S, Leo G, Alexandrovich A et. al. The cannabinoid CB1 receptor regulates bone formation by modulating adrenergic signaling. FASEB J. 2008;22(1):285-294.

57. Hudson BD, Hébert TE, Kelly ME. Physical and functional interaction between $\mathrm{CB} 1$ cannabinoid receptors and beta2-adrenoceptors. $\mathrm{Br} \mathrm{J}$ Pharmacol. 2010;160(3):627-642.

58. Prasanna X, Chattopadhvay A, Sengupta D. Cholesterol modulates the dimer interface of the $\beta_{2}$-adrenergic receptor via colesterol occupancy sites. Biophys J. 2014;106(6):1290-1300.

59. Shukla AK, Westfield GH, Xiao K, Reis RI, Huang LY, Shukla PT, et. al. Visualization of arrestin recruitment by a $G$ protein-coupled receptor. Nature. 2014:512(7513):218-222.

60. Luttrell LM, Lefkowitz RJ. The role of $\beta$-arrestins in the termination and transduction of G-protein-coupled receptor signals. J Cell Sci. 2002:115(Pt 3):455-465.

61. Nelson CD, Kovacs JJ, Nobles KN, Whalen EJ, Lefkowitz RJ. Beta-arrestin scaffolding of phosphoinositol 4-phsphate 5-kinase lalpha promotes agonist-stimulated sequestration of the b2-adrenergic receptor. J Biol Chem. 2008:283(30):21093-21101.

62. Nobles KN, Xiao K, Ahn S, Shukla AK, Lam ChM, Rajagopal S, et. al. Distinct phosphorylation sites on the $\beta 2$-adrenergic receptor establish a barcode that encodes differential functions of $\beta$-arrestin. Sci Signal. 2011;4(185):ra51.

63. Shenoy SK, Lefkowitz RJ. $\beta$-arrestin-mediated receptor trafficking and signal transduction. Trends Pharmacol Sci. 2011;32(9):521-533.

64. Tao J, Malbon CC. G-protein-coupled receptor-associated A-kinase anchoring proteins AKAP5 and AKAP12: differential signaling to MAPK and GPCR recycling. J Mol Signal. 2008;3:19.

65. Gao S, Wang HY, Malbon CC. AKAP12 and AKAP5 form higher-order hetero-oligomers. J Mol Signal. 2011;6:8.

66. Vanotis G, Del-Duca D, Trieu P, Rohlicek CV, Hébert TE, Allen BG. Nuclear $\beta$-adrenergic receptors modulate gene expression in adult rat heart. Cell Signal. 2011;23(1):89-98.

67. Wright CD, Chen Q, Baye NL, Huang Y, Healy CL, Kasinathan S, et al. Nuclear $\alpha_{1}$-adrenergic receptors signal activated ERK localization to caveolae in adult cardiac myocytes. Circ Res. 2008;103(9):992-1000.

68. Lyssand JS, Whiting JL, Lee K-S, Kastl R, Wacker JL, Bruchas MR, Miyatake M, Langeberg LK, Chavkin Ch, Scott JD, Gardner RG, Adams ME, Hague Ch. $\alpha$-dystrobrevin-1 recruits $\alpha$-catulin to the $\alpha$ adrenergic receptor/dystrophin-associated protein complex signalosome. Proc Natl Acad Sci U S A. 2010;107(50):21854-21859.

69. De-La-Torre Russis V, Valles A, Gómez R, Chinea G, Pons T. Interacciones proteína-proteína: bases de datos y métodos teóricos de predicción. Biotecnología Aplicada. 2003;20(3):201-208. 